\title{
Emergence of transnational clusters: Evidence from the Slovak automotive industry*
}

Peter Zámborsky ${ }^{* *}$

We explore the evolution of automotive clusters in Slovakia from the emergence to growth stages of their life cycles and investigate how the clusters spill over national borders. We also analyze how clusters and their transnationality affect firm competitiveness. Our findings suggest that although the clusters have an overall positive impact on competitiveness of participating firms, it is not the transnational cluster linkages that matter most for the emerging clusters. Linkages with firms in the same group in Central Europe matter more for competitiveness than shared institutions and linkages arising from geographic proximity.

Wir beforschen die Entwicklung der Automobilbranche in der Slowakei von ihrer Entstehung bis zur Wachstumsphase ihres Lebenszyklus und untersuchen wie die Cluster nationale Grenzen überschreiten. Wir analysieren zudem, wie die Cluster und ihre Transnationalität sich auf die Wettbewerbsfähigkeit der Unternehmen auswirken. Unsere Ergebnisse deuten daraufhin, dass obwohl die Cluster eine generell positive Auswirkung auf die Wettbewerbsfähigkeit der beteiligten Firmen haben, es nicht die transnationalen Verbindungen zwischen den Clustern ist, die die größte Bedeutung für die neu entstehenden Cluster haben. Verbindungen mit Firmen der gleichen Gruppe in Zentraleuropa sind bedeutsamer für die Wettbewerbsfähigkeit als gemeinsame Institutionen und Beziehungen, die auf geografischer Nähe beruhen.

Keywords: cluster life-cycle, transnationality, competitiveness, automotive

\footnotetext{
* Manuscript received: 8.12.2011 accepted:19.01.2012 (0 revision)

** Lecturer in Management and International Business, University of Auckland Business School, New Zealand. Main research areas: Host country effects of foreign direct investment, performance of international joint ventures, international plant location strategy, transnational clusters and competitiveness. Corresponding address: p.zamborsky@auckland.ac.nz
} 


\section{Introduction}

While globalisation, market integration and technological revolution provide a number of challenges to firms today, they also provide many opportunities. This is particularly true for companies in small Central and Eastern European countries that lack the domestic market necessary for growth and suffer from relatively weak infrastructure. Recognizing these insufficiencies and potential weaknesses, many countries in post-socialist Europe have promoted development of regional clusters where firms can develop their competences and competitive advantages against the world's best competitors by sharing resources, innovative capabilities, and knowledge.

A number of researchers (e.g. Piore/Sabel 1984; Saxenian 1994; Porter, 1998; Martin/Sunley 2003) have acknowledged the value of clusters, pointing to the advantages they provide for the development, transfer, and application of knowledge necessary for continued innovation. By clustering together, firms are able to pull from a common and accessible pool of resources, information, and demand for innovation to build competences and create competitive advantages to compete globally.

Successful development of such clusters, however, is proving problematic in many countries. This study focuses on the emergence of automotive clusters in Central Europe and particularly in Slovakia. While clusters in the new EU members from Central and Eastern Europe have been analysed before (OECD 2005; Sölvell et al. 2008) and so was the automotive industry in the region (Rhys 2004; Dyker 2006), there is so far no study that would tackle both of these issues together in sufficient depth. Moreover, while the clusters in the automotive industry have been analysed rigorously in the North American context (Rutherford et al. 2008; Sturgeon et al. 2008), there is so far limited literature tackling this issue in Europe (Lung 2004; MacNeill/Chanaron 2005). The transnational dimension of clusters is overlooked in studies from both these regions.

The Central European automotive clusters are important and interesting because new EU members account for a rising and relatively high share of EU car production (about $20 \%$ in 2010, according to the European Automobile Manufacturers Association). Slovakia, Slovenia and the Czech Republic are the world's leading car producers per capita. The objective of this study is to explain the emergence and growth of the Slovak automotive cluster(s), investigate their transnational dimension and impact on competitiveness. In addition to filling a gap in the literature on emerging clusters (Fornahl et al. 2010), we aim to contribute to the debate on the changing face of the European periphery in the automotive industry (Domanski/Lung 2009) and add to a debate on regional vs. global strategy in the automotive industry in strategic management (Schlie/Yip 2000; Rugman/Collinson 2004). 


\section{Theory and literature review}

Porter (1998) defined clusters as geographic concentrations of interconnected companies and institutions in a particular field. In an alternative definition in the same article, he suggested that clusters are critical masses - in one place - of unusual competitive success in particular fields. These two definitions reveal a tension between an economic geography definition of a cluster and a strategic management definition, as mere geographic concentration of firms and institutions in a region may not guarantee competitiveness of firms located there.

Porter (1998) suggests a number of channels by which geographically concentrated firms may obtain a competitive boost and help a cluster to grow:

- Better access to employees and suppliers

- Access to specialized information

- Complementarities between industries

- Access to institutions and public goods

- Better motivation and measurement

- Impact of clusters on innovation

- Impact of clusters on new business formation

While Porter discusses clusters in an international context and uses examples ranging from California to Portugal, his framework does not provide a complete explanation of the emergence and competitiveness of what we term 'transnational clusters' - defined as geographic concentrations of interconnected companies and institutions spanning national borders - that have been arising in the European Union recently. In its treatment of the 'transnational' concept, the cluster theory has so far focused on the relationship between transnational corporations and regional clusters, but failed to focus on the potentially transnational aspect of the cluster itself (Karlsson 2008; Ter Wal 2010; Mudambi/Swift, 2012). Recent policy initiatives from the European Commission are encouraging these transnational clusters (and use the terminology of 'transnational cluster') with a new 2009 initiative on Transnational Alliance for Clusters towards Improved Cooperation Support (TACTICS). The Baltic Sea Region Stars Programme-spanning Scandinavia, northern Germany and the Baltic countries from the former Soviet Union-is a flagship cluster cooperation of this type.

Sölvell et al. (2008) use Porter's cluster mapping approach to measure industrial specialization and agglomeration in regions of the ten new EU members states, but also fail to recognize that clusters often span borders. Sölvell (2009) focuses on evolutionary and constructive forces in nation-based clusters but fails to acknowledge that the economies of external scale that Porter (1998) suggested as key factors boosting competitiveness of cluster firms often arise in transnational regions where opportunities for learning can be greater because of 
diversity of the firms and countries (although there are also hindrances to cluster effects due to national cultural differences, regulatory and trade barriers etc.).

Sturgeon et al. (2008) have applied cluster and global value chain theory to the world automotive industry and suggested a nested geographic and organizational structure with four levels:

- A global industry

- Regional production systems (several nations - i.e. NAFTA or EU)

- National production systems

- Local clusters

They suggest that national production is still very strong in this industry, and still dominates many national markets, with intra-regional (say inside of the European Union) of finished vehicle and parts flows being the dominant operational pattern in this industry. Their discussion suggests regional networks matter as much for competitiveness as local clusters do, and that both are best to be analyzed as two aspects of the global value chain. While we agree that the global value chain context matters in this industry, at the plant level it is also worth investigating the changing importance of ties within a cluster and ties with firms outside of the cluster, whether they are members of the company group or not. In concentrated (focused) and well-developed clusters, the relations within the cluster may matter more than relations with firms from farther afield. This potential effect of the cluster depth is also related to the cluster life cycle (Bergman 2007), as we need to take into account the fact that the clusters in Central and Eastern Europe have only emerged recently.

This study explores how the relationship between clusters, their transnationality and competitiveness relates to the cluster life cycle, particularly the transition from the cluster 'emergence' to 'growth' stages. We use the definitions of cluster stages from Menzel and Fornahl (2009), who present a model of the stages of the cluster life cycle (emergence, growth, decline and renewal of clusters) and how they depend on the technological heterogeneity of firms in the cluster. They suggest that the number of cluster employees/firms and the heterogeneity of accessible knowledge in the cluster are the key dimensions of the cluster life cycle. The emerging clusters start with few employees/firms and an increasing heterogeneity of accessible knowledge, while growing and sustained clusters are increasing employee/firm/start-up numbers and decreasing the heterogeneity of companies' competencies inherent in the cluster.

The model of Menzel and Fornahl (2009) implies that linkages to knowledge flows outside the cluster (say through the corporate group network or global value chain relationships) can pull the clustered firms apart and create new technological distances that can prevent the emerging cluster from growing. This consideration is likely to be particularly relevant in the context of the 
Central European car industry, where clusters have tended to emerge around anchor multinationals with headquarters from outside of the region.

Four major research questions emerge from the theoretical and literature review:

- How has a firm's location in an automotive cluster affected its competitiveness?

- Which were the main channels of cluster's potential impact on competitiveness?

- How does cluster transnationality contribute to cluster growth/competitiveness?

- How do linkages with organizations inside/outside of the cluster affect cluster growth?

\section{Methods}

To answer the research questions and develop more explicit hypotheses that might explain cluster growth and the relationship between cluster transnationality and competitiveness, we have conducted a field trip to Slovakia and the Czech Republic to investigate the emergence and growth of two automotive clusters centered in Slovakia. The qualitative research method was chosen because of the early stage of cluster development (especially across borders). Slovakia was chosen because there are three major automotive producers located there in close proximity: German Volkswagen and French PSA Peugeot Citroën located in Western Slovakia and Kia Motors in Northern Slovakia. It was also chosen because of its location in the center of Europe, with a potential to study transnational clusters spilling over from Slovakia to neighboring Hungary, Austria, the Czech Republic and Poland. Taking into account the fact that clusters involve firms as well as institutions, we have not only interviewed representatives of key car companies and cluster directors, but also the Slovak Automotive Industry Association, a mayor of Trnava where PSA and Automotive Cluster Western Slovakia are located, and a director of the Professional MBA Automotive Industry Programme at the Slovak University of Technology, which is a joint degree (global offer) with a sister institution in neighboring Austria (see Table 1 for a list of interviews). 
Table 1: Interviewed organisations

\begin{tabular}{|l|l|l|}
\hline $\begin{array}{l}\text { Organisation } \\
\text { code (see Figures } \\
\mathbf{1} \text { \& 2) }\end{array}$ & $\begin{array}{l}\text { Position/name of } \\
\text { Interviewed person }\end{array}$ & $\begin{array}{l}\text { Name/location } \\
\text { of the organisation }\end{array}$ \\
\hline Firm 1.1 & $\begin{array}{l}\text { Spokesperson } \\
\text { Vladimír Machalík }\end{array}$ & $\begin{array}{l}\text { Volkswagen Slovakia } \\
\text { Bratislava, Slovakia }\end{array}$ \\
\hline Firm 2.1 & $\begin{array}{l}\text { Senior Manager } \\
\text { Dušan Dvoŕák }\end{array}$ & $\begin{array}{l}\text { Kia Motors Slovakia } \\
\text { Žilina, Slovakia }\end{array}$ \\
\hline Institution 1 & $\begin{array}{l}\text { Academic Director } \\
\text { (STU) } \\
\text { Prof. Dr. Ing. Ján } \\
\text { Lešinský }\end{array}$ & $\begin{array}{l}\text { Slovak University of Technology } \\
\text { (STU) Professional MBA } \\
\text { Automotive Industry, Bratislava, } \\
\text { Slovakia }\end{array}$ \\
\hline Institution 2 & $\begin{array}{l}\text { Secretary General } \\
\text { Mária Nováková }\end{array}$ & $\begin{array}{l}\text { Slovak Automotive Industry } \\
\text { Association, Bratislava, Slovakia }\end{array}$ \\
\hline Institution 3 & $\begin{array}{l}\text { Mayor } \\
\text { Štefan Bošnák }\end{array}$ & $\begin{array}{l}\text { City of Trnava } \\
\text { Trnava, Slovakia }\end{array}$ \\
\hline Institution 4 & $\begin{array}{l}\text { Director } \\
\text { Štefan Chudoba }\end{array}$ & $\begin{array}{l}\text { Automotive Cluster Western } \\
\text { Slovakia } \\
\text { Trnava, Slovakia }\end{array}$ \\
\hline Institution 5 & $\begin{array}{l}\text { Director } \\
\text { Ladislav Glogar }\end{array}$ & $\begin{array}{l}\text { Automotive Cluster Moravia } \\
\text { Silesia } \\
\text { Ostrava, Czech Republic }\end{array}$ \\
\hline
\end{tabular}

\section{Results and discussion}

\section{Growth of major car-makers in Slovakia}

The automotive industry in Slovakia is clustered around three major car makers, each producing over 100,000 cars per year:

Volkswagen produced 106,000 cars in 2009 with revenues of $2.94 \mathrm{bn}$ euro. Its Slovak plants are the sole global producers of SUV flagship products of the VW Group such as Audi Q7 and Volkswagen Touareg (with a significant percentage of Porsche Cayenne's content produced in Slovakia as well);

PSA Peugeot Citroën produced over 203,000 cars in 2009 with revenues of 1.8bn euro, about half of cars were Peugeot 207 for the EU market and half Citroën C3 Picasso for the world market;

Kia produced 150,000 cars in 2009 with 1.68 bn revenues, mostly their cee'd model designed specifically for the EU market, but also Sportage SUV for Europe and other regions.

Volkswagen has been in Slovakia from 1991, gradually increasing its production from a couple thousand to over 200,000 cars per year in early 2000s, when PSA and Kia made a decision to locate in Slovakia. Štefan Bošnák, the mayor of 
Trnava, where PSA Peugeot Citroën decided to locate its plant after considering competing locations in Hungary and Poland, recalls that one of the factors influencing PSA's decision was a visit to Volkswagen's plant in Bratislava organized by Jozef Uhrík, then CEO of Volkswagen Slovakia but also the President of the Automotive Industry Association of Slovakia. The French executives were impressed with the quality of workers and the proactive approach of the Slovak government and municipal officials, who offered French investors tax holidays, free land and considerable other assistance in setting up their plant in Trnava. Many of the employees of Volkswagen, PSA and Kia were graduates of the Slovak Technical University and students of Prof. Dr. Ján Lešinský. He made himself famous in the media by suggesting that Slovakia can accommodate more than one and perhaps three major car factories that might potentially benefit from clustering benefits of supplier proximity and access to pools of qualified labour, such as the graduates of the Professional MBA Automotive Industry Programme offered jointly by the Slovak University of Technology and the Austrian Vienna University of Technology. "Cluster is a state of mind,' says Prof. Dr. Lešinský, "it's about institutions that bind companies with an invisible social glue."

Kia arrived in Slovakia in 2004 and started its full year of production in 2007. Dušan Dvořák, its senior PR manager, says that there are limits to the benefits of proximity to other car plants. PSA, for example, has reportedly asked for a special clause in its investment contract with the Slovak Republic, stipulating that no other major car manufacturer is located within $100 \mathrm{~km}$ of Trnava, PSA's Slovak location. Indeed, Mr Dvořák admits that Koreans were happy to locate further north to benefit from relatively high unemployment rates in northern Slovakia that fed its 3,000-strong workforce. "We have definitely reaped benefits of joint negotiations (of the three car makers) with the Slovak government about the business environment and other joint issues of concern." Kia has also benefited from a proximity to its sister Hyundai plant across the border in the Czech region of Moravia/Silesia (less than $100 \mathrm{~km}$ from Žilina, where Kia Motors Slovakia is located), according to Mr Dvořák.

\section{Emergence of automotive clusters in Slovakia}

The three major car makers in Slovakia can be grouped into two major clusters. Volkswagen and PSA, about $100 \mathrm{~km}$ from each other, are both located in Western Slovakia and are close to Hungarian automotive clusters in the Székesfehérvár and Györ regions as well to Austria that is home to a number of car suppliers such as Magna. Trnava, the seat of PSA, is also the location of the office of the only official cluster facilitator in the Slovak automotive industry: Automotive Cluster Western Slovakia. The cluster institution was a brainchild of Trnava's mayor Štefan Bošnák, who wanted to see more development in the supply sector to the automotive industry and in small and medium-sized 
enterprises that can link and benefit in various ways from the anchor foreign investor. Štefan Chudoba, a veteran of the Slovak automotive industry who was in the management of a 5,000-person utility vehicle TAZ plant in Trnava during the communist times, took on the job after assignments with the Volkswagen group in Slovakia and Russia. Mr Chudoba says that his vision for the cluster is to encourage more start-up firms with innovative potential and to link the cluster to other European clusters through the automotive network and autoclusters.eu project.

He also thinks across the industries, suggesting that the plastic materials cluster in the neighboring Czech Moravia region can serve as an inspiration and potential partner to his members in the Slovak automotive supply sector. Indeed, Western Slovakia's cluster seems to be more about suppliers, who make up for about $45 \%$ of the Slovak car industry sales, rather than producers. Notably, PSA is not a member of the Western Slovak cluster and also decided not to participate in this research project. Mr Chudoba says that PSA Group is not shy to be a member of cluster initiatives in France, but that it still views Slovakia as more of production site rather than a place where innovative technologies are born out of joint collaborative initiatives. "The only chance of innovative breakthroughs being developed in Slovakia is to do it in the supplier sector, perhaps in collaboration with some of the research institutes or centres of excellence such as the Institute of Welding or Trnava's Applied Materials Department of the Slovak University of Technology," says Mr Chudoba.

Vladimir Machalík of Volkswagen is a bit more upbeat about the potential of the participation of car makers in the development of Western Slovak automotive cluster. Mr Machalík, who was previously with the European Commission working on assignment related to cluster projects, admits that Slovak clusters are still in their early stages but that all the car makers are benefiting from the arrival of major international car suppliers that were attracted by the high concentration of car makers in Slovakia and Central Europe. The cluster concentration also pushes upwards the standards of education, according to $\mathrm{Mr}$ Machalík. Although not much formal collaboration is being done by Volkswagen and PSA Peugeot Citroën so far, the two car companies may increasingly see many intersecting interests and benefit from shared services, he says.

The second emerging automotive cluster in Slovakia (although not formally organized from the Slovak side) is located in its northwestern corner, where Kia has its plant. This cluster has potentially a transnational dimension, as Hyundai's plant is across the border in the Czech Republic and major global car producers in the Polish Katowice/Silesian region are located less than $200 \mathrm{~km}$ from both Kia's and Hyundai's plants. This cluster is better developed from the Czech side, where Ladislav Glogar, a former executive of Ford's Czech component factory, runs a Moravian Silesian Automotive Cluster. The Slovak side of this 
emerging cluster is still looking more to VW and PSA to the south rather than GM and Fiat in Poland to the north of them, according to Mr Dvořák (see Figure $1)$.

Figure 1: National perspective on clusters around the Slovak automotive industry

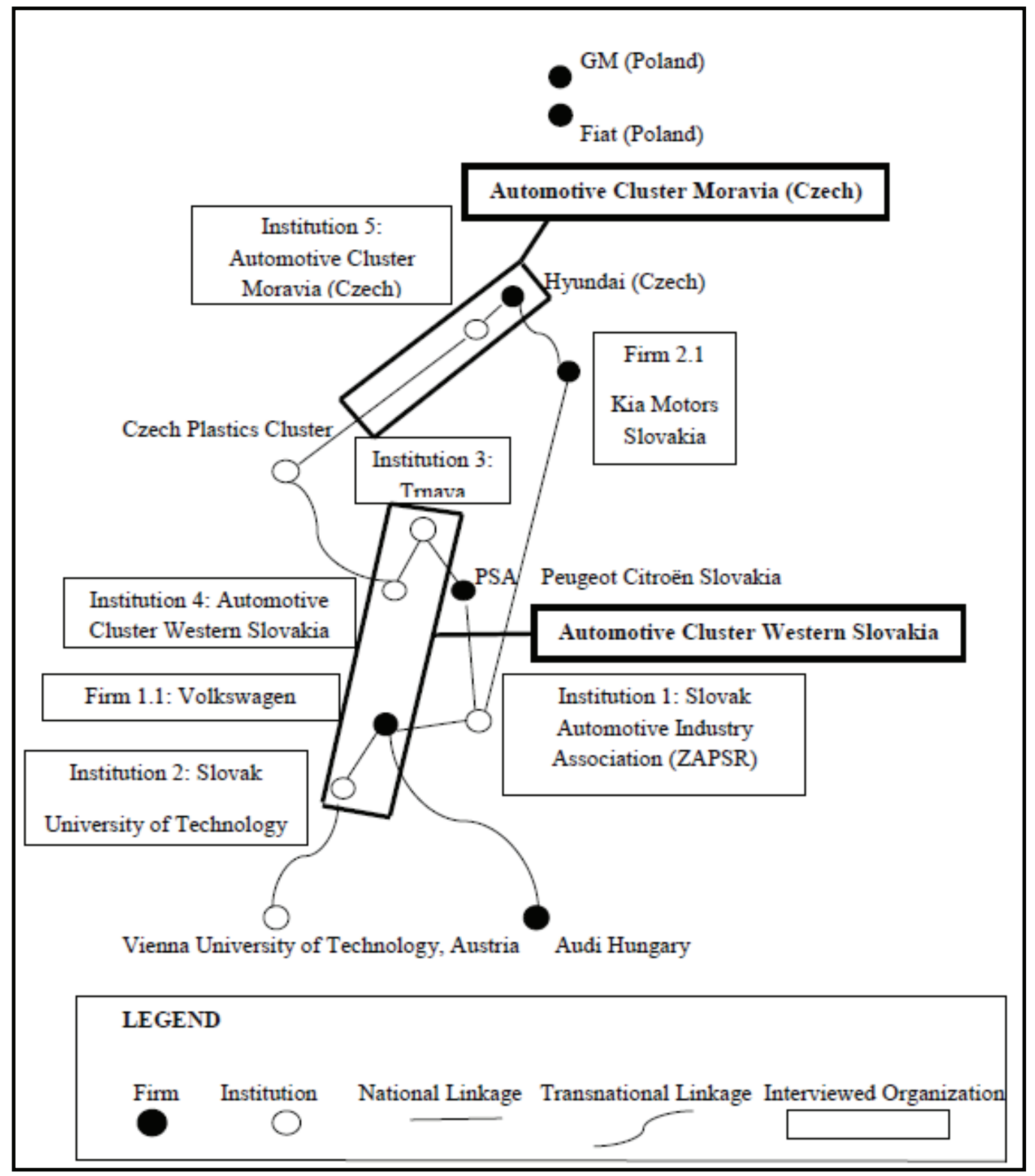

\section{Clusters and competitiveness}

Both Volkswagen and Kia representatives have agreed that their location in a cluster has had a positive impact on their companies' competitiveness (compared to other plants of their automotive group and compared to competing Europe-based automotive producers not located in their cluster). Maria 
Nováková, the Secretary General of the Slovak Automotive Industry Association (ZAPSR), said that revenues of the Slovak automotive suppliers doubled after PSA and Kia's arrival. Supplies for these two car makers overcame supplies for VW from 2007, according to ZAPSR. Revenues of Slovak-based automotive suppliers rose at an average annual rate of $28.7 \%$ between 2000 and 2008, according to ZAPSR. Volkswagen Slovakia sourced $37.7 \%$ of its purchases from Slovak-based suppliers (most of them in Western Slovakia), more than from Germany (34.4\%), Hungary $(9.8 \%)$ or the Czech Republic (5.5\%) in the late 2000s, according to VW. However, the Slovak automotive industry is still dominated by car producers, who accounted for about $55 \%$ of the industry's revenues in 2008, according to ZAPSR. The Czech Republic has a higher share of car suppliers on the car industry's production (48\% in 2010), according to Mr Glogar of the Moravian Silesian Automotive Cluster. This could have made the country more resilient in the face of financial crisis, which has depressed car production in Slovakia by $20 \%$ from 575,000 in 2008 to 461,000 in 2009. The Czechs produced more than a million of cars in 2010 and were one of the few countries in EU that didn't see an annual drop in car production in 2009.

Mr Glogar says that a cluster membership can have a concrete short term impact on competitiveness through cost saving in purchasing and long term impact in research and development activities. He was able to show a few projects where he could say that his members benefited significantly from an initiative facilitated by Mr Glogar's cluster. One example is a joint R\&D project with the local technical Universities in Ostrava and Zlín and four other cluster members and three common laboratories. "Many of cluster events, such as vocational training in an 'automotive academy', joint purchasing etc. bring positive impacts on competitiveness, but the impact is only occasionally dramatic," according to Mr Glogar. "Competitiveness and cluster growth are long-term processes."

\section{Channels in the link between clusters and competitiveness}

Representatives of Volkswagen and Kia have both put sharing resources (mostly suppliers) and knowledge (more specifically personnel) as the channels of effect of the cluster on competitiveness. Mr Dvorák of Kia has also stressed the improved negotiating position with the Slovak government when it came to talks about the labour code and other labour issues and issues related to the improvements in the business environment. Mr Machalík of Volkswagen has also suggested that the concentration of car makers and suppliers in Western Slovakia and nearby regions has put an upward pressure on the quality of technical and vocational training education in this region, benefiting both Volkswagen and PSA. The companies did not mention the sharing of innovative capabilities as an important channel linking clusters and competitiveness, 
suggesting that Slovak clusters are still not reaching the highest value added aspect of the value chain.

\section{Cluster transnationality and competitiveness}

Both Volkswagen and Kia have noted that the proper dimension of the cluster is transnational/ transregional. For Volkswagen, their vision of the cluster stretches from Western Slovakia (where PSA has a plant) to Central Slovakia (where Volkswagen has a dedicated transmission factory in Martin) to Hungary (where Audi, a part of the VW Group, produces engines for VW's Slovak Bratislava site, see Figure 2). Kia definitely see themselves as members of the cluster with their sister Hyundai plant in Czech Nošovice, with some linkages southward to central Slovakia (a large base of suppliers for all Slovak car makers) and Poland (with car makers and suppliers such as French Saint Gobin that supplies glass for Kia's windows). Both Messrs Machalík and Dvořák agree that automotive networks are transnational today and Central Europe is perhaps the proper dimension for linking cluster transnationality and competitiveness. However, they still see the transnational effect more in their own group and do not see cluster transnationality per se as an advantage. Mr Glogar from the Czech Moravian Silesian Automotive Cluster agrees, saying that he is focusing on a wide range of Tier 1 suppliers, rather than original equipment manufacturers (OEMs), so that he helps to create supply chains with SMEs. In the first phase, his cluster focuses on delivery of concrete results as a base for long term vision about a transnational cluster. "Our cluster has to be able to show from the beginning results to SMEs to motivate them for cooperation." This gradual approach towards cluster transnationality is somewhat different from a grander vision pursued from the beginning by Mr Chudoba of the Western Slovak cluster. He is trying to reach out to fellow clusters in the Czech Republic, Central and Southeastern Europe and encourage learning and cooperation between them. Some of the institutions in his cluster, such as the Slovak University of Technology, are keen on building transnational ties too. 
Figure 2: Transnational perspective on clusters around the Slovak automotive Industry



\section{Internal/external cluster linkages and growth}

Both car companies interviewed have admitted that linkages outside of the cluster are still more important than those inside of the emerging cluster(s), highlighting the continued importance of network relationships within their own business group. Volkswagen's vision of the cluster is more a picture of affiliated plants and suppliers of the VW Group in the Central European area rather than a closely knit Western Slovakian cluster. Kia and Hyundai also see themselves as 
twin plants of the same group with a number of dedicated suppliers and some non-exclusive suppliers being conveniently located in relative proximity. Comments from both companies seem to suggest that intra-cluster linkages are not strong enough yet and clusters in Slovakia are still in their juvenile years so that intra-cluster linkages can't be assigned a major role in firm's competitive strategies and competitiveness.

However, when forced to rank these intra-cluster linkages in terms of their contribution to competitiveness, VW has stressed linkages to other plants of their group and to their suppliers, while Kia has highlighted linkages to suppliers (no. 1) and governments and other institutions (perhaps seeing its twin Hyundai plant as the same entity as themselves). On a micro-regional level, which is often associated with clusters in high-tech industries (such a life sciences cluster around the Massachusetts Institute of Technology and the Massachusetts General Hospital in Boston), there are first signs of co-location of related institutions and firms in business incubators in Czech Ostrava or in the new Science and Technology Park to be opened in Slovak Trnava. However, these are still taking shape and do not have significant effects yet. It seems that the relatively strong linkages to knowledge flows outside of the cluster rather than participation in building the linkages/institutions inside of the cluster are limiting the growth of the Slovak clusters from 'emergence' to 'growth' stage, in line with theoretical predictions derived from Menzel and Fornahl (2009).

\section{Other results}

Both companies saw their respective clusters focusing on vehicle assembly and parts production rather than R\&D and design. More interestingly, while VW saw the Slovak government and the Slovak Automotive Industry Association as key non-business actors shaping their cluster competitiveness, Kia put the Slovak government as no. 1 but stressed the European Commission as no. 2 influence, with reference to tariffs and anti-dumping legislation which concerns the Korean producer significantly.

\section{Conclusions}

Volkswagen's Slovak production site was established in 1991 and was a part of the company's strategy to benefit from the political and economic upheavals following the fall of the Berlin Wall in 1989. It was not clear how fast Eastern Europe will develop and what parts of the Western car maker's production processes may be productively moved there. Using a cautious 'salami' tactics, VW initially used the Slovak site as a back-up for meeting peaks in demand and did not commit substantial resources in a big bang approach. Twenty years later, with gradual but consistent growth, VW Slovakia is the only production location for the group's flagship SUVs such as Audi Q7 or Volkswagen Touareg. Moreover, the first versions of VW's "New Small Family" generation of eco- 
friendly city concept cars of Volkswagen (including VW Up!, Skoda Citigo and SEAT Mii) are produced there to prepare the group for another turbulent decade following the great recession of 2009. VW's first-mover strategy in Eastern Europe was brave and improved its European and global competitiveness.

Its followers from France (PSA Peugeot Citroën) and South Korea (Kia), who came to Slovakia in the 2000s, were hoping to jump on the bandwagon and had to consider the potential effects of geographic concentration and clustering of car producers/suppliers in such a small country/region. Kia has agreed with Volkswagen that clustering had some positive effects on competitiveness. However, in spite of two formal automotive cluster facilitators established in Slovakia and the neighboring Czech Republic, and nearby clusters in Hungary and Austria (and automotive agglomeration in Polish Silesia region), the transnational dimensions of the clusters do not seem to be very strongly related to competitiveness so far, according to the interviewed cluster stakeholders. Traditional cluster-competitiveness channels such as sharing suppliers and personnel seem to matter more than sharing innovative capabilities, suggesting that the clusters are still in their early stages of development and linkages within them are still relatively weak and don't matter than much for competitiveness yet. Geographic proximity matters, but at the moment more in terms of group or other (supplier) affiliations than rather than in terms of traditional cluster linkages and institutions.

This study has reported results of field research on the cluster emergence and growth in the automotive industry in Slovakia and Central Europe. We also reported on the growing international linkages and competitiveness of firms and institutions in this region and how this is related to clusters. A limitation of the study is that it did not survey suppliers in depth, although they were partly discussed in the results. It is possible that cluster effects will be stronger at the supplier level. Overall, the study has added new support about the changing face of the European periphery in the automotive industry (Domanski/Lung 2009) and shed new light on cluster life cycle theory (Menzel/Fornahl 2009). Our main novel theoretical contribution is that emerging clusters (Fornahl et al. 2010) can grow via transnational linkages. Our empirical findings from the underresearched Western Slovakia and Moravia-Silesia automotive clusters present new evidence on how national and transnational cluster evolution and growth strategies affect competitiveness. We conclude that transnational linkages can lead to a higher competitiveness but after a longer time lag than national ones.

\section{References}

Bergman, E. M. (2007): Cluster life cycles: an emerging synthesis, in C. Karlsson (ed.), Handbook of research on cluster theory. Cheltenham, UK: Edward Elgar Publishing, 114-132. 
Domanski, B./Lung, Y. (2009): The changing face of the European periphery in the automotive industry, in: European Urban and Regional Studies, 16, 5, 5-10.

Dyker, D. (2006): Contrasting patterns in the internationalization of supply networks in the motor industries of emerging economies, in: Post-Communist Economies, 18, 2, June, 190-204.

Fornahl, D./Henn S./Menzel M. (2010): Emerging clusters: theoretical, empirical and political perspectives on the initial stage of cluster evolution. Cheltenham, UK: Edward Elgar Publishing.

Karlsson, Ch. (2008): Handbook of research on cluster theory. Cheltenham, UK: Edward Elgar Publishing.

Lung, Y. (2004): The changing geography of the European automobile system, in: International Journal of Automotive Technology and Management, 4, 2/3, 137-165.

MacNeill, S./Chanaron, J. (2005): Trends and drivers of change in the European automobile industry, in: International Journal of Automotive Technology and Management, 5, 1, 83-106.

Martin, R./Sunley, P. (2003): Deconstructing clusters: chaotic concept or policy panacea?, in: Journal of Economic Geography, 3, 5-35

Menzel, M./Fornahl, D. (2009): Cluster life-cycles-dimensions and rationales of cluster evolution, in: Industrial and Corporate Change, 19, 1, 205-238.

Mudambi, R./Swift, T. (2012): Multinational enterprises and the geographic clustering of innovation, in: Industry and Innovation, 19, 1 (forthcoming)

OECD (ed.) (2005): Business clusters: promoting enterprise in Central and Eastern Europe, Paris, France.

Piore, M./Sabel, Ch. (1984): The second industrial divide. New York: Basic Books.

Porter, M. (1998): Clusters and the new economics of competition, in: Harvard Business Review, November-December, 77-90.

Rhys, G. (2004): The motor industry in an enlarged EU, in: World Economy, 27, 877-900.

Rugman, A./Collinson, S. (2004): The regional nature of the world's automotive sector, in: European Management Journal, 22, 5, 471-482.

Rutherford, T./Holmes, J. 2008: The flea on the tail of the dog: power in the global production networks and the restructuring of Canadian automotive clusters, in: Journal of Economic Geography, 8, 519-544.

Saxenian, A. 1994: Regional advantage: culture and competition in Silicon Valley and Route 128. Cambridge, MA: Harvard University Press.

Schlie, E./Yip, G. (2000): Regional follows global: strategy mixes in the world automotive industry, in: European Management Journal, 18, 4, 343-354.

Sölvell, O./Ketels Ch./Lindqvist G. (2008): Industrial specialization and regional clusters in the ten new EU member states, in: Competitiveness Review, 18, 1/2, 104-130.

Sölvell, O. (2009): Clusters: balancing evolutionary and constructive forces. Stockholm, Sweden: Ivory Tower Publishers. 
Sturgeon, T/van Biesenbroeck, J./Gereffi G. (2008): Value chains, networks and clusters: reframing the global automotive industry, in: Journal of Economic Geography, 8, 297321.

Ter Wal, A. (2010): Cluster emergence and network evolution: a longitudinal analysis of the inventor network in Sophia-Antipolis, in: Regional Studies, 45, 1-1 